\title{
Body Weight and Steroidal Implants Impact Animal Growth Performance, Sera Metabolites, and Pulmonary Arterial Pressure in Feedlot Cattle
}

\author{
Tyler A. Vogel ${ }^{1}$, Joseph M. Neary¹, Zachary K. Smith ${ }^{2 *}$, Bradley J. Johnson ${ }^{1}$ \\ ${ }^{1}$ Department of Animal and Food Science, Texas Tech University, Lubbock, TX, USA \\ ${ }^{2}$ Department of Animal Science, South Dakota State University, Brookings, SD, USA \\ Email: ${ }^{\star}$ zachary.smith@sdstate.edu
}

How to cite this paper: Vogel, T.A. Neary, J.M., Smith, Z.K. and Johnson, B.J. (2020) Body Weight and Steroidal Implants Impact Animal Growth Performance, Sera Metabolites, and Pulmonary Arterial Pressure in Feedlot Cattle. Open Journal of Animal Sciences, 10, 414-430.

https://doi.org/10.4236/ojas.2020.103026

Received: April 17, 2019

Accepted: June 15, 2020

Published: June 18, 2020

Copyright $\odot 2020$ by author(s) and Scientific Research Publishing Inc. This work is licensed under the Creative Commons Attribution International License (CC BY 4.0).

http://creativecommons.org/licenses/by/4.0/

\begin{abstract}
The study objective was to evaluate steer growth performance, sera metabolite responses, carcass characteristics, and pulmonary arterial pressure as affected by body weight at time of implantation and steroidal implant administration. Crossbred steers $(n=20)$ were used in a $2 \times 2$ factorial arrangement of treatments in a completely randomized design experiment, Factors included: body weight: light (L), or heavy (H) and implant: Non-implanted (NoIMP), or Implanted (IMP) with steer serving as the experimental unit for all analyses. Initial weights for $\mathrm{L}$ and $\mathrm{H}$ steers were $398 \pm 27.6$ and $547 \pm 25.2 \mathrm{~kg}$, respectively. Implanted steers received a terminal implant $(200 \mathrm{mg}$ trenbolone acetate and 20 mg estradiol-17 $\beta$; Revalor-200; Merck Animal Health, Madison, NJ) on d 0 . Cattle within treatments were group housed in common pens $(n=5$ steers/pen). Bodyweight, blood samples, and pulmonary arterial pressure were collected on $\mathrm{d} 0,14,35,70$ and 104. Cattle were fed a common diet once daily to provide ad libitum access to feed. The finishing diet contained (DM basis) $13.3 \% \mathrm{CP}, 2.13 \mathrm{Mcal} / \mathrm{kg} \mathrm{NEm}$, and $1.45 \mathrm{Mcal} / \mathrm{kg} \mathrm{NEg}$. Growth performance (body weight and $\mathrm{ADG}$ ) and carcass traits were analyzed using the MIXED procedure of SAS 9.4 (SAS Inst. Inc., Cary, NC). Sera metabolites were analyzed as repeated measures over time, with day as the repeated measure. For all analyses, $\alpha$ level $<0.05$ determined significance. Heavy steers consumed $2.2 \mathrm{~kg}$ more per head of DM daily than L cattle and IMP steers consumed $1.0 \mathrm{~kg}$ more DM daily than NoIMP steers. Cumulative ADG did not differ between the $\mathrm{L}$ and $\mathrm{H}$ steers ( 1.41 vs. $1.52 \pm 0.060 \mathrm{~kg} ; P=0.20$ ). Implanting increased $(P<0.01)$ ADG by $39 \%(1.22$ vs. $1.70 \pm 0.060 \mathrm{~kg})$. No differences $(P>0.05)$ in ADG were observed in NoIMP vs. IMP cattle beyond $\mathrm{d}$ 70 (1.21 vs. $1.01 \pm 0.16 \mathrm{~kg} ; P=0.38$ ). Sera urea-N concentrations were de-
\end{abstract}


creased $(P<0.01)$ in L cattle subjected to IMP during the study and tended to increase over time for the other treatments. Ribfat, HCW, LM, marbling score, calculated YG, and estimated EBF were greater $(P \leq 0.05)$ in $\mathrm{H}$ compared to L. Steers from IMP had heavier HCW $(P<0.01)$ but decreased marbling scores $(P=0.05)$ compared to NoIMP. Mean pulmonary arterial pressure was greater $(P<0.01)$ for $\mathrm{H}$ compared to $\mathrm{L}$ steers which may predispose heavier cattle to right-sided heart failure. The steroid implant had no effect on pulmonary arterial pressure $(P>0.49)$. The study reaffirms the effects of implanting on animal growth performance and carcass characteristics in cattle. In addition, elevated BW leads to increased pulmonary arterial pressures which may increase the risk of right-sided heart failure.

\section{Keywords}

Cattle, Estradiol, Pulmonary Pressure, Trenbolone

\section{Introduction}

Growth enhancing technologies such as implants have been used in the cattle industry since the early 1950's [1]. Steroid implants have been documented to increase $\mathrm{ADG}$ by $18 \%$, increase feed intake by $6 \%$, improve feed efficiency by $8 \%$, and increase carcass weight by $5 \%$ [1] [2] [3]. Research by [4] has shown both live and carcass weights have continued to increase over the last 50 years. They also reported an increase in mortality in both steers (27.6\%) and heifers (30.5\%) in the same survey [4]. Neary, Booker, Wildman and Morley [5] observed an increase in mortality due to cardiac failure as cattle weights increased. An ancillary effect of steroids is their ability to affect pulmonary arterial pressure. Estrogens have been documented to reduce pulmonary hypertension in humans [6] [7] [8] although limited information on the effects of estradiol-17 $\beta$ $\left(\mathrm{E}_{2}\right)$ and trenbolone acetate (TBA) on pulmonary pressure have been reported. In addition, with increasing live and carcass weights limited research has been conducted, which looks at the growth performance differences of implants in cattle of differing body weights. Therefore, the objectives of this research were to evaluate BW at time of implant administration and steroidal implant application on animal growth performance, carcass characteristics, sera metabolites responses, and pulmonary arterial pressure in feedlot cattle.

\section{Materials and Methods}

All experimental procedures involving the use of animals were reviewed and approved by the Texas Tech University Institutional Animal Care and Use Committee (\#16064). The experiment was conducted at the Texas Tech University Burnett Center located approximately $10.0 \mathrm{~km}$ East of New Deal, TX.

\section{Steer growth performance}

Crossbred beef steers $(n=20 ; 339 \mathrm{~kg})$ were delivered to the Texas Tech Uni- 
versity Burnett Center in New Deal, TX during the summer of 2016. Steers were placed in a large group pen and offered a $70 \%$ concentrate receiving diet. Steers were fed the $70 \%$ concentrate diet for $5 \mathrm{~d}$ and subsequently transitioned to an $80 \%$ concentrate diet. Upon initiation of the trial, steers were fed a $90 \%$ concentrate finishing diet. During arrival processing steers were identified with a unique individual ear tag. All steers were vaccinated for viral respiratory pathogens using Bovishield Gold 5 (Zoetis Animal Health, Parsippany, New Jersey), clostridial species using Vision 7 (Merck Animal Health, Madison, NJ), mycoplasma bovis using Myco-Bac B (Texas Vet Lab, San Angelo, TX), and treated internal and external parasites using with Safeguard (Merck Animal Health) and Ivomec (Merial Animal Health, Duluth, GA). Steers were weighed using a Silencer squeeze chute (Moly Manufacturing, Inc., Lorraine, KS; accuracy + 0.5 $\mathrm{kg}$ ) on d-14. The steers were then blocked into two BW categories: light (L) or heavy $(\mathrm{H})$, with the 10 lightest steers assigned to the L category and the 10 heaviest steers to the $\mathrm{H}$ category. On $\mathrm{d}-1$ cattle were weighed and within each body weight category were sorted by increasing BW and alternately assigned to one of two implant treatments: Non-implant (NoIMP), or Implant (IMP). Steers assigned to the IMP treatment received an implant containing $200 \mathrm{mg}$ TBA and 20 mg of $E_{2}$ (Revalor-200, Merck Animal Health, Madison, NJ). On d 0 cattle were weighed again with the average weight of $\mathrm{d}-1$ and $\mathrm{d} 0$ as the initial BW. Initial BW at study initiation for $\mathrm{L}$ and $\mathrm{H}$ steers were 398 and $547 \mathrm{~kg}(\mathrm{SEM}=9.7 \mathrm{~kg})$, respectively. Steer served as the experimental unit for all analyses.

All steers within similar BW class and implant treatments were housed in a common pen. Steers were fed once daily with feed mixed and delivered in a drag-type Rotomix feed wagon $\left(2.35 \mathrm{~m}^{3}\right.$; scale readability $0.5 \mathrm{~kg}$; Dodge City, KS). Steers were fed a $90 \%$ concentrate ration throughout the study in the morning (0800 to $0900 \mathrm{~h}$ ). Feed delivery was adjusted to provide ad libitum access while reducing wasted feed.

The total mixed ration was sampled weekly throughout the course of the study and split into 2 aliquots as described by [9]. One aliquot of the weekly sample was immediately taken and dried in duplicate in a forced air oven at $100^{\circ} \mathrm{C}$ for $24 \mathrm{~h}$ in order to determine DM content of the diet, which was then utilized to determine total DMI for each week. At the conclusion of the study the second aliquot of the weekly diet samples, were composited by $28 \mathrm{~d}$ period for chemical analyses of $\mathrm{CP}, \mathrm{ADF}, \mathrm{NDF}$, and ash content (DairyOne, Ithaca, NY) using AOAC procedures. Diet composition and chemical analysis of the $90 \%$ concentrate diet can be found in Table 1.

Orts were collected, weighed and dried in a forced air oven at $100^{\circ} \mathrm{C}$ for $24 \mathrm{~h}$ in order to determine DM content if carryover feed went out of condition, or was present on weigh days. If carryover feed was present on weigh days, the residual feed was removed prior to the collection of BW measurements. The DMI of each pen was adjusted to reflect the total DM delivered to each pen after subtracting the quantity of dry orts for each interim period. 
Table 1. Ingredient formulation and nutrient composition of finishing diet.

\begin{tabular}{cc}
\hline Ingredient & $\% \mathrm{DM}$ \\
\hline Steam-flaked corn & 64.56 \\
Wet corn gluten feed & 20.07 \\
Alfalfa hay & 7.93 \\
Fat (yellow grease) & 3.07 \\
Supplement ${ }^{1}$ & 1.99 \\
Calcium Carbonate & 1.87 \\
Urea & 0.51 \\
\hline Nutrient composition ${ }^{2}$ & $\% \mathrm{DM}^{3}$ \\
\hline Dry Matter, \% & 78.32 \\
Crude Protein, \% & 13.27 \\
Neutral Detergent Fiber, \% & 16.60 \\
Acid Detergent Fiber, \% & 8.38 \\
Ash, \% & 4.48 \\
Net Energy Maintenance, Mcal $/ \mathrm{kg}$ & 2.13 \\
Net Energy Gain, Mcal $/ \mathrm{kg}$ & 1.45 \\
\hline
\end{tabular}

${ }^{1}$ Supplement composition (DM basis): $67.755 \%$ Cottonseed meal, $15.000 \%, \mathrm{NaCl}, 10.000 \% \mathrm{KCl}, 3.760 \%$ Urea, $0.986 \%$ Zinc sulfate, $0.750 \%$ Rumensin-90 (Elanco, Greenfield, IN), 0.506 Tylan-40 (Elanco), $0.500 \%$ Endox (Kemin Industries, Des Moines, IA), $0.196 \%$ Copper sulfate, $0.167 \%$ Manganese oxide, $0.157 \%$ vita$\min \mathrm{E}(500 \mathrm{IU} / \mathrm{g}), 0.125 \%$ selenium premix $(0.2 \% \mathrm{Se}), 0.083 \%$ iron sulfate, $0.010 \%$ vitamin $\mathrm{A}(1,000,000$ $\mathrm{IU} / \mathrm{g}), 0.003 \%$ ethylenediamine dihydroiodide, and $0.002 \%$ cobalt carbonate. ${ }^{2}$ Composition from 6 samples that were composited by interim weigh period from weekly diet samples and analyzed at a commercial laboratory (Dairy One Forage Laboratory, Ithaca, NY). Diet DM determined weekly (forced-air oven for $24 \mathrm{~h}$ at $\left.100^{\circ} \mathrm{C}\right) .{ }^{3}$ All values except for dry matter on a DM basis.

Cattle health was evaluated daily between 0700 and 0900 for signs of illness or injury. Two steers were treated for foot rot (d 14 and d 20) with one steer removed from the L/NoIMP treatment due to lameness. Steer weights, blood samples, and heart pressure measurements were obtained on $\mathrm{d} 0,14,35,70$ and 104 prior to the daily feed delivery.

\section{Sampling procedures}

Blood samples were collected and pulmonary arterial pressure was determined for all steers on d 0,14, 35, 70 and 104. Animal were restrained in a hydraulic squeeze chute for sample collections. Following aseptic preparation of the neck (chlorhexidine solution), a 12-gauge, $8.9-\mathrm{cm}$ needle was inserted into the jugular vein. A flexible, saline-filled polyethylene catheter tubing (external and internal diameter of 17 and $12 \mathrm{~mm}$, respectively) was fed through the needle, down into the right atrium, followed by the right ventricle, and then into the pulmonary artery. A pressure transducer was connected the catheter to an oscilloscope (BM5Vet, Bionet America, Inc. Tustin, CA, U.S.A.). The position of the catheter tip within the vascular system was determined from the pressure waveform on the oscilloscope. Blood was collected using a saline-filled pressure catheter with approximately $15 \mathrm{ml}$ of whole blood collected from the 12-gauge needle in the 
jugular vein for harvesting of serum for subsequent sera metabolite analyses. The entire procedure took approximately 4 to 5 minutes per animal. A full description of the equipment, materials and facilities required for pulmonary arterial pressure testing was described by [10]. Final BW was collected on d 104. Seven d later steers were placed in adjacent holding pens, loaded on a truck, and shipped $(198 \mathrm{~km})$ to harvest at Tyson Fresh Meats, Inc., Amarillo, TX. Individual carcass measurements included hot carcass weight (HCW), loin muscle area (LMA), ribfat (RF), marbling score, kidney-pelvic-heart fat (KPH), and USDA yield grade were collected by trained West Texas A\&M University as described by [11]. Carcass data from one steer in H/IMP treatment group was not collected due to carcass condemnation. Estimated empty body fat percentage (EBF) was calculated using the formula described by [12] [13].

\section{Sera metabolite analyses}

Following sampling collection, blood was transferred from the Burnett Research Center to an assay lab at the Texas Tech University Animal and Food Science building. Blood was stored in a refrigerator at $4^{\circ} \mathrm{C}$ for 24 hours. Blood was subsequently brought to room temperature and spun in a centrifuge at 4000 $\times \mathrm{g}$ for 20 minutes at $4^{\circ} \mathrm{C}$ and harvested as sera. Sera samples were divided into 2 $\mathrm{ml}$ polystyrene tubes for $17-\beta$ trenbolone $(17 \beta-\mathrm{TbOH})$, insulin-like growth factor I (IGF-I), non-esterified fatty acid (NEFA) and sera urea-N (SUN) analyses.

Circulating $17 \beta$-TbOH concentration was quantified via liquid chromatography-tandem mass spectrometry (LC-MS/MS) using the same method described by [14] [15]. Blank $(n=3)$ and spiked $(n=3)$ matrix (bovine serum, Sigma-Aldrich, St. Louis, MO) samples were analyzed along with 42 unknowns per sample batch (48 extractions in total) in order to monitor extraction method performance. No steroids were observed above the limit of detection in any solvent or matrix blank. The mean matrix spike recovery for sera was $114 \% \pm 9.2 \%$. Solvent blanks and check standards were included every 8 and 16 samples, respectively, in instrument runs for QC purposes. The limit of quantification, as determined by the lowest calibration standard included in sample runs, was 25 $\mathrm{pg} / \mathrm{mL}$ serum. Values below the limit of quantification were assigned the value for trenbolone- $17 \beta$ of $12.5 \mathrm{pg} / \mathrm{mL}$ serum.

Circulating IGF-I concentration was quantified via ELISA procedures (Quantikine Human IGF-I ELISA, R \& D Systems, Minneapolis, MN). Samples were assayed according to manufacturer recommendations as described by [16]. Prior to analysis raw sera samples were extracted in order to reduce IGF binding protein interference. The standard curve constructed for the IGF-I assay was between 9.4 and $600.0 \mathrm{ng} / \mathrm{mL}$. For the IGF-I analysis the intra-assay CV was less than $10 \%$ and the inter-assay CV was less than $10 \%$. The IGF-I samples were run in duplicate and determinations were considered for re-runs if the coefficient of variation between duplicate determinations was greater than $10 \%$.

The quantification of circulating NEFA concentration was determined using triplicate $5 \mu \mathrm{L}$ determinations via colorimetric assay using a commercially available kit that involved acyl-CoA synthase, acyl-CoA oxidase, and peroxidase in 96 
well microtiter plates (NEFA-HR; Wako Diagnostics, Richmond, VA). Using identical procedures to those described by others [16] [17]. The standard curve constructed for the NEFA assay was between 0 and $1.0 \mathrm{mEq} / \mathrm{L}$. For the NEFA analysis, the intra-assay CV was less than $10 \%$ and the inter-assay CV was less than $10 \%$. Samples were considered for re-runs if the coefficient of variation among the absorbance values for triplicate determinations was greater than $5 \%$.

The quantification of circulating serum urea-N (SUN) concentration was determined on a microplate spectrophotometer in triplicate $5 \mu \mathrm{L}$ determinations, using diacetylmonoxime via a commercially available kit (STANBIO Urea Nitrogen-0580; STANBIO Laboratory, Boerne, TX). The standard curve constructed for the SUN assay was between 0 and $25.0 \mathrm{mg} / \mathrm{dL}$ [16]. For the SUN analysis the intra-assay CV was less than $10 \%$ and the inter-assay CV was less than $10 \%$. Samples were considered for re-runs if the coefficient of variation among the absorbance values for triplicate determinations was greater than $5 \%$.

\section{Statistical Analyses}

For all analyses, individual steer was considered the experimental unit. Growth performance and carcass data were analyzed as a $2 \times 2$ factorial arrangement and included the fixed effects of weight class and implant as well as their interaction using the MIXED procedure of SAS 9.4 (SAS Inst., Inc., Cary, NC). Sera metabolite responses and heart pressure measurements were analyzed as repeated measures appropriate for a $2 \times 2$ factorial arrangement using the MIXED procedure of SAS 9.4 (SAS Inst. Inc., Cary, NC). The statistical model included the fixed effects of body weight at implantation time, implant treatment and day as well as all possible interactions; day was included as the repeated variable and steer served as the experimental unit ( $\mathrm{n}=5$ steers/simple treatment mean). The covariance structure with the lowest Akaike information criterion (AIC) was used [18]. All results are reported as least-squares means. Data means were separated using the PDIFF option of SAS if a significant preliminary F-test was detected. An $\alpha$ level of 0.05 was used to determine significance, with tendencies discussed at $P$-values between 0.051 and 0.10 . A significant $\mathrm{d} 0$ effect (relative to implant) was found for IGF-I and SUN. To account for that affect, $\mathrm{d} 0$ was included as a covariate in the model for analysis of those metabolites.

\section{Results and Discussion}

Cattle within the same treatment were grouped into common pens. Thus, statistical analyses were not conducted for dry matter intake (DMI) and feed conversion (G:F). However, the $\mathrm{H}$ cattle consumed numerically $2.2 \mathrm{~kg}$ more DM per d during the $104 \mathrm{~d}$ study than the $\mathrm{L}$ cattle. As the study progressed, the H/IMP treatment group consumed numerically the most DM intake. Implanted steers consumed numerically $1.0 \mathrm{~kg}$ more per $\mathrm{d}$ than NoIMP steers over the course of the study. Others have reported increased DMI when steers were administered steroidal implants with anabolic activity [9] [11] [16] [19] [20] [21]. The effects of cattle weight and implant status on animal growth performance are shown in Table 2. 
Table 2. Growth performance responses of light and heavy weight steers given no implant or administered a steroidal implants. ${ }^{1,2}$

\begin{tabular}{|c|c|c|c|c|c|c|c|c|}
\hline \multirow[b]{2}{*}{ Item } & \multicolumn{2}{|c|}{ Body Weight (BW) } & \multicolumn{2}{|c|}{ Implant (Imp) } & \multirow[b]{2}{*}{ SEM } & \multicolumn{3}{|c|}{$P$-values } \\
\hline & Light & Heavy & No Implant & Implant & & BW & $\operatorname{Imp}$ & $\mathrm{BW} \times \operatorname{Imp}$ \\
\hline \multicolumn{9}{|c|}{ Body weight, kg } \\
\hline Initial & 398 & 547 & 474 & 470 & 9.7 & $<0.01$ & 0.78 & 0.88 \\
\hline d 14 & 406 & 566 & 483 & 489 & 9.5 & $<0.01$ & 0.64 & 0.56 \\
\hline d 35 & 454 & 606 & 520 & 540 & 11.3 & $<0.01$ & 0.20 & 0.96 \\
\hline d 70 & 502 & 672 & 560 & 613 & 11.5 & $<0.01$ & $<0.01$ & 0.77 \\
\hline d 104 & 544 & 705 & 601 & 647 & 12.7 & $<0.01$ & 0.02 & 0.51 \\
\hline \multicolumn{9}{|c|}{ Initial to $\mathrm{d} 14$} \\
\hline ADG, kg & 0.61 & 1.35 & 0.62 & 1.34 & 0.195 & 0.02 & 0.02 & 0.02 \\
\hline DMI, kg & 6.10 & 9.44 & 7.42 & 8.13 & - & - & - & - \\
\hline G:F & 0.100 & 0.143 & 0.083 & 0.165 & - & - & - & - \\
\hline \multicolumn{9}{|l|}{ d 15 to 35} \\
\hline $\mathrm{ADG}, \mathrm{kg}$ & 2.26 & 1.93 & 1.75 & 2.44 & 0.182 & 0.22 & 0.02 & 0.21 \\
\hline DMI, kg & 8.40 & 11.22 & 9.44 & 10.18 & - & - & - & - \\
\hline G:F & 0.268 & 0.172 & 0.186 & 0.239 & - & - & - & - \\
\hline \multicolumn{9}{|l|}{ d 36 to 70} \\
\hline $\mathrm{ADG}, \mathrm{kg}$ & 1.37 & 1.87 & 1.16 & 2.08 & 0.098 & $<0.01$ & $<0.01$ & 0.43 \\
\hline DMI, kg & 8.31 & 10.57 & 8.78 & 10.09 & - & - & - & - \\
\hline G:F & 0.165 & 0.177 & 0.132 & 0.206 & - & - & - & - \\
\hline \multicolumn{9}{|l|}{ d 71 to 104} \\
\hline $\mathrm{ADG}, \mathrm{kg}$ & 1.24 & 0.98 & 1.21 & 1.01 & 0.161 & 0.24 & 0.38 & 0.36 \\
\hline DMI, kg & 7.91 & 9.31 & 8.12 & 9.10 & - & - & - & - \\
\hline G:F & 0.157 & 0.105 & 0.149 & 0.111 & - & - & - & - \\
\hline \multicolumn{9}{|c|}{ Initial to 104} \\
\hline $\mathrm{ADG}, \mathrm{kg}$ & 1.41 & 1.52 & 1.22 & 1.70 & 0.063 & 0.20 & $<0.01$ & 0.14 \\
\hline DMI, kg & 7.90 & 10.14 & 8.52 & 9.52 & - & - & - & - \\
\hline G:F & 0.178 & 0.150 & 0.144 & 0.179 & - & - & - & - \\
\hline
\end{tabular}

${ }^{1}$ No shrink was applied to any body weight measures. ${ }^{2}$ Implanted steers received a $200 \mathrm{mg}$ trenbolone acetate and $20 \mathrm{mg}$ estradiol-17 $\beta$ implant at study initiation (Revalor-200, Merck Animal Health, Madison, NJ).

There was an interaction $(P<0.02)$ of $\mathrm{BW} \times \mathrm{IMP}$ detected for ADG from 0 to 14 d. Daily gains were $0.60,0.62,0.63$ and $2.07 \mathrm{~kg} / \mathrm{d}$ for steers in L/NoIMP, L/IMP, $\mathrm{H} /$ NoIMP, and H/IMP, respectively. Likely the difference in daily gain for steers in the H/IMP treatment was attributable to increased DMI during this period. Beyond d 14, there were no interactions between body weight and implant status $(P>0.14)$ on ADG. Therefore, only the main effects are discussed. At study initiation, steers in the $\mathrm{H}$ weight block were $149 \mathrm{~kg}$ heavier $(P<0.01)$. This weight difference remained relatively constant for the duration of the study. The $\mathrm{H}$ cat- 
tle finished the study approximately $161 \mathrm{~kg}$ heavier $(P<0.01)$ than L steers. During the entire study, there was no difference in rate of ADG between $\mathrm{L}$ and $\mathrm{H}$ steers $(P=0.20)$. Cattle in the $\mathrm{H}$ groups gained at a faster rate $(P<0.01)$ from d 36 to 70 , while during the final $33 \mathrm{~d}$, the L cattle gained numerically faster than $\mathrm{H}$ steers $(P=0.24)$. Implanted steers gained faster through the first $70 \mathrm{~d}$ compared to NoIMP cattle $(P<0.02)$. Implanted steers gained more than $0.48 \mathrm{~kg} / \mathrm{d}$ faster than NoIMP steers throughout to course of the experiment. Implanting increased $(P<0.02)$ ADG during days 0 to 14,15 to 35 , and 36 to 70 ; however, there was no difference $(P=0.38)$ in animal growth performance during the final 33 days on feed. This might suggest the effect of the implant was diminished beyond $\mathrm{d} 70$ since there was not a difference in animal growth performance beyond this time.

The effects of body weight and implant status on carcass characteristics are reported in Table 3. Cattle in the $\mathrm{H}$ treatment groups had greater HCW than cattle in the $\mathrm{L}$ treatment groups $(P<0.01)$. As expected, cattle in the $\mathrm{H}$ groups had a larger LMA $(P=0.04)$ and greater RF $(P=0.04)$ than the L steers. Heavier cattle also exhibited greater marbling scores $(P=0.01)$, increased yield grade ( $P$ $=0.03)$ and estimated $\mathrm{EBF} \%(P<0.01)$ compared to the $\mathrm{L}$ treatment groups. These differences were expected given the differences in the intial and final weight due to experimental design. Implanted treatment groups had heavier HCW than cattle in the non-implanted treatment groups $(P<0.01)$. This increase in HCW is commonly seen when steroidal implants are administered to feedlot finishing steers [20] [21] [22]. Further, there was no difference between implanted and non-implanted treatment groups with respect to LMA, RF, calculated yield grade and estimated $\mathrm{EBF} \%$, which is not consistent to what others have demonstrated [14] [19]. However, implanted cattle exhibited lower marbling scores $(P=0.05)$ compared to the non-implanted treatment groups and this decrease in marbling for cattle harvested at equal days on feed is well noted in the literature [19] [20] [21] [22].

Table 3. Carcass trait responses of light and heavy weight steers given no implant or administered a steroidal implants. ${ }^{1}$

\begin{tabular}{|c|c|c|c|c|c|c|c|c|}
\hline \multirow[b]{2}{*}{ Item } & \multicolumn{2}{|c|}{ Body Weight (BW) } & \multicolumn{2}{|c|}{ Implant (Imp) } & \multirow[b]{2}{*}{ SEM } & \multicolumn{3}{|c|}{$P$-values } \\
\hline & Light & Heavy & No Implant & Implant & & BW & $\operatorname{Imp}$ & $\mathrm{BW} \times \operatorname{Imp}$ \\
\hline $\mathrm{HCW}, \mathrm{kg}$ & 342 & 445 & 376 & 412 & 8.3 & $<0.01$ & $<0.01$ & 0.29 \\
\hline Dressing, $\%^{2}$ & 62.9 & 62.3 & 62.5 & 62.7 & 0.60 & 0.47 & 0.86 & 0.97 \\
\hline Loin muscle area, $\mathrm{cm}^{2}$ & 88.4 & 99.1 & 92.0 & 95.5 & 3.41 & 0.04 & 0.48 & 0.18 \\
\hline Ribfat, cm & 1.13 & 1.69 & 1.38 & 1.45 & 0.172 & 0.04 & 0.77 & 0.18 \\
\hline Marbling score ${ }^{3}$ & 421 & 559 & 541 & 439 & 34.2 & 0.01 & 0.05 & 0.69 \\
\hline Kidney-pelvic-heart fat, \% & 1.88 & 1.94 & 1.88 & 1.94 & 0.108 & 0.69 & 0.69 & 0.24 \\
\hline Yield grade & 2.47 & 3.37 & 2.82 & 3.03 & 0.260 & 0.03 & 0.57 & 0.06 \\
\hline Estimated EBF, \% & 27.5 & 32.5 & 30.1 & 30.0 & 1.00 & $<0.01$ & 0.96 & 0.16 \\
\hline
\end{tabular}

${ }^{1}$ Implanted steers received a $200 \mathrm{mg}$ trenbolone acetate and $20 \mathrm{mg}$ estradiol-17 $\beta$ implant at study initiation (Revalor-200, Merck Animal Health, Madison, NJ). ${ }^{2} \mathrm{HCW} /$ final body weight from d $104 .{ }^{3}$ marbling score of $400=$ small $^{00}$. 
Sera levels of $17 \beta-\mathrm{TbOH}$ are illustrated in Figure 1. There was an IMP $(P<$ $0.01)$ effect on TBoh concentration however and this is similar to what others have demonstrated post-implantation [14] [16] [17] [19], there was no IMP $\times$ BW interaction $(P=0.21)$ noted in the present experiment. Sera concentrations of $17 \beta$ - TbOH were greater in $\mathrm{L}$ compared to $\mathrm{H}$ steers on days 14,35 , and 104 with the lone exception occurring on $\mathrm{d} 70$ when sera concentrations of $17 \beta-\mathrm{TbOH}$ were greater in $\mathrm{H}$ steers. Sera concentrations of $17 \beta$-TbOH ranged from 0 to $1643 \mathrm{pg} / \mathrm{ml}$ for L cattle and 288 to $2527 \mathrm{pg} / \mathrm{ml}$ in $\mathrm{H}$ cattle on $\mathrm{d}$ 70. It is possible the release of TBA from the compressed pellets might have been variable given the erratic numbers found on $\mathrm{d} 70$. Generally speaking, TBA concentrations for the $\mathrm{L}$ cattle reached a peak on $\mathrm{d} 35$ and declined thereafter. For the $\mathrm{H}$ cattle TBA concentrations did not reach their peak until $\mathrm{d} 70$ and decreased after.

Sera IGF-I concentrations due to BW and implant are shown in Figure 2. A d 0 effect $(P<0.02)$ was observed in which IGF-I concentrations were elevated for the L/IMP cattle. To account for this, $\mathrm{d} 0$ was included as a covariate in the model. There was a three-way interaction between $\mathrm{BW} \times \mathrm{IMP} \times$ Day $(P<0.02)$. Body weight did not affect IGF-I concentration $(P>0.99)$ while implanting increased $(P<0.01)$ IGF-I concentrations and sera IGF-I concentrations decreased with days on feed $(P<0.01)$. It is interesting to note IGF-I levels between IMP and NoIMP separated for $\mathrm{H}$ cattle by $\mathrm{d} 14$ while IGF-I concentration in L cattle were similar on d 14 between IMP and NoIMP and then separated on d 35. A hallmark sign of steroidal implant administration in beef cattle in increased sera IGF-I [14] [17].

When evaluating the effects of BW and implant status on sera NEFA concentrations, there was no effect $(P=0.81)$ of $\mathrm{BW}$ on sera NEFA concentrations (Figure 3$)$. There was no effect of implants on sera NEFA concentrations $(P<$

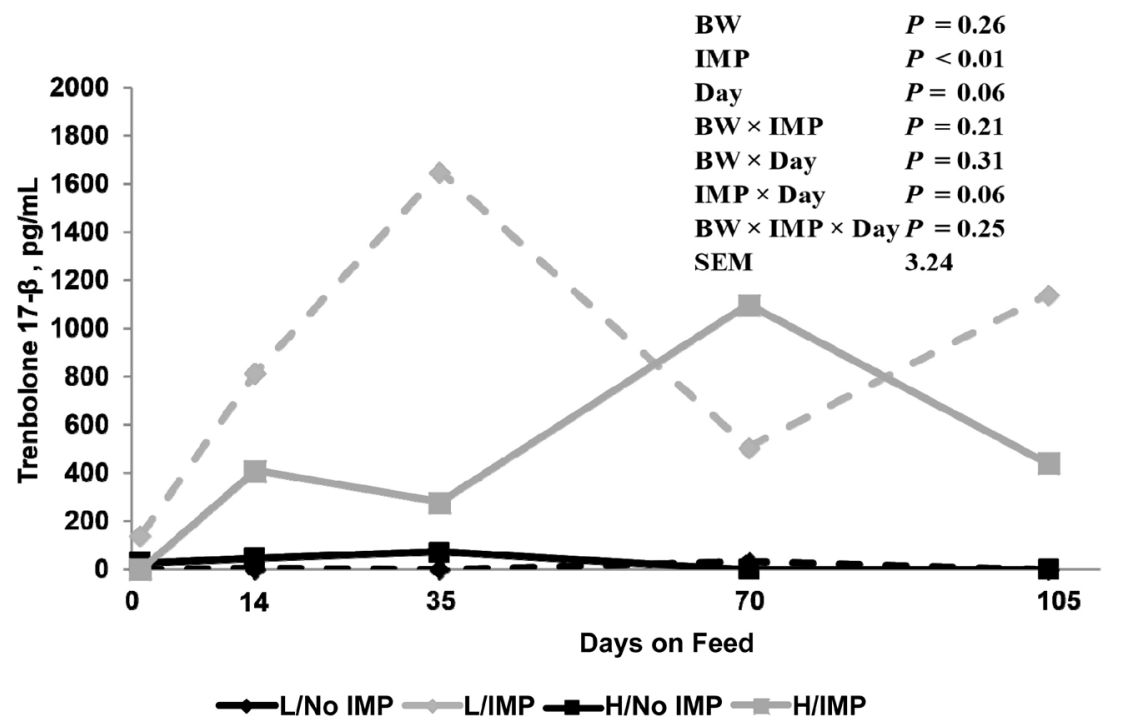

Figure 1. Effect of body weight and implant usage on Trenbolone 17- $\beta$ (TBOH) concentration $(\mathrm{L}=$ Light $\mathrm{BW} ; \mathrm{H}=$ Heavy BW; NoIMP = Non-implanted; IMP = Implanted; $\mathrm{SEM}=3.24 ; \mathrm{n}=5$ steers/treatment). 


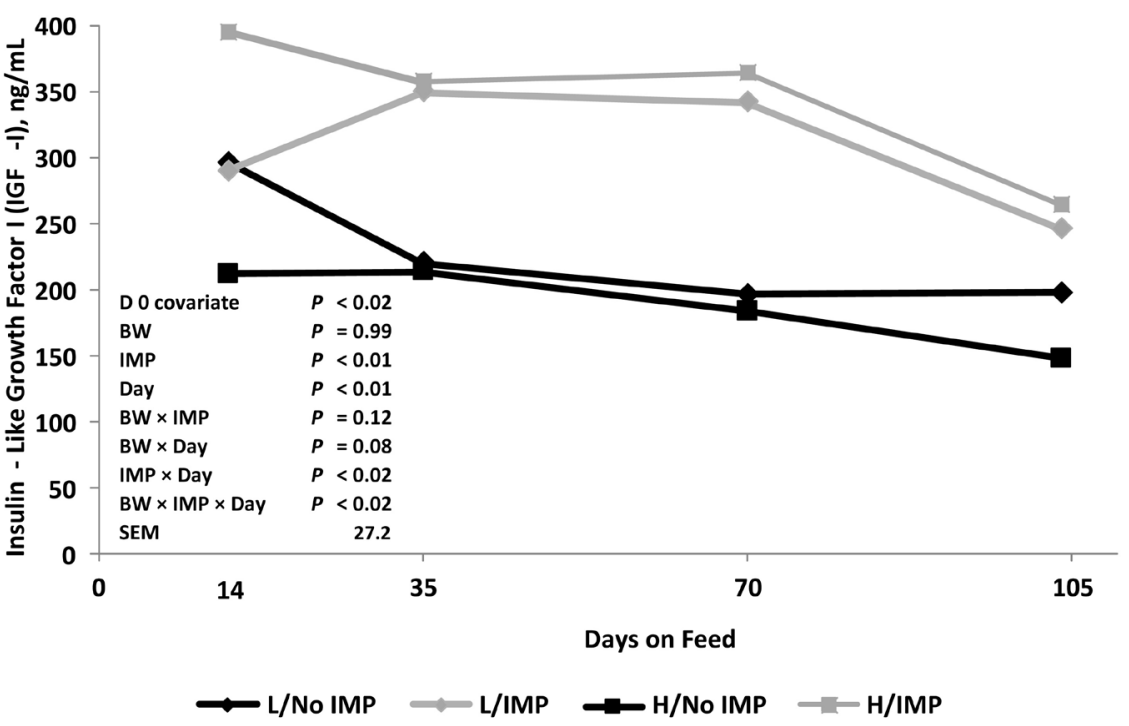

Figure 2. Effect of body weigh and implant usage on Insulin-Like Growth Factor I concentration using d 0 values as a covariate ( $\mathrm{L}=$ Light $\mathrm{BW} ; \mathrm{H}=$ Heavy BW; NoIMP = Nonimplanted; IMP = Implanted; SEM = 27.2; $\mathrm{n}=5$ steers $/$ treatment ).

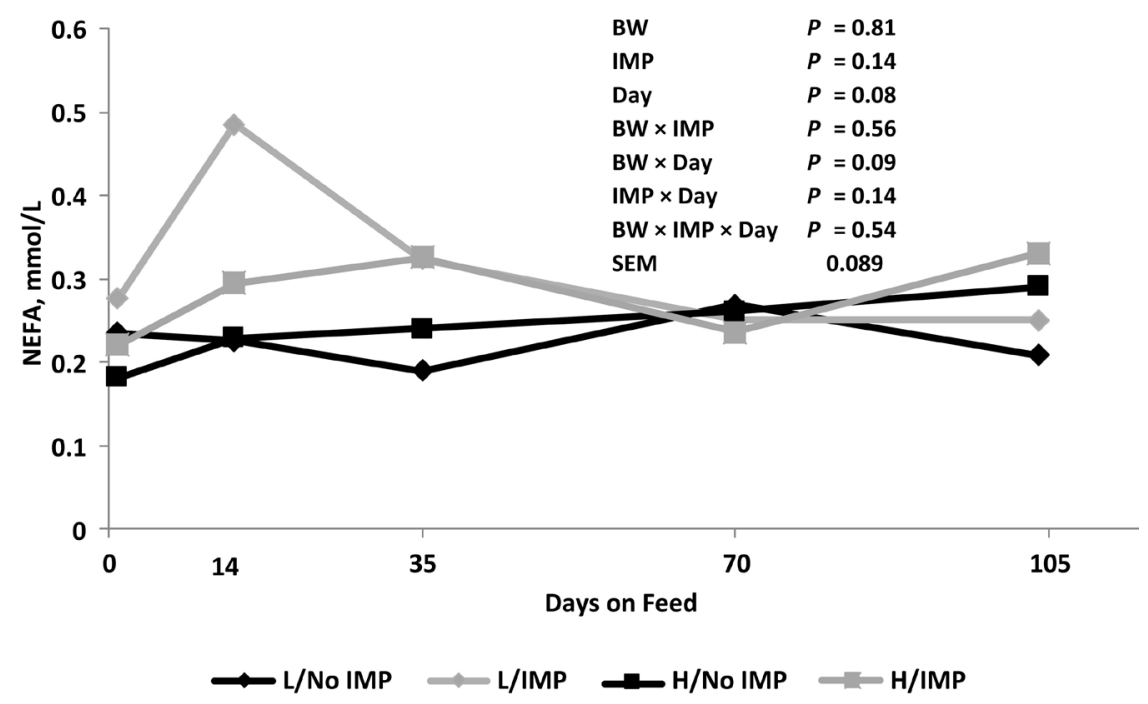

Figure 3. Effect of body weight and implant usage on NEFA concentration (L = Light BW; $\mathrm{H}=$ Heavy BW; NoIMP = Non-implanted; IMP = Implanted; SEM $=0.089 ; \mathrm{n}=5$ steers/treatment).

0.14). This response has been confirmed by others previously [16] [17] [23]. Sera NEFA concentrations tended $(P=0.08)$ to be elevated on $\mathrm{d} 14$ in the L/IMP steers indicating that implants resulted in rapid mobilization of fat early in the feeding period. There was a tendency $(P=0.08)$ for NEFA concentration to increase with increasing days on feed. This is not surprising as cattle became heavier with increased adiposity with increasing days on feed.

Sera urea-N concentrations are reported in Figure 4. A d 0 effect $(P<0.02)$ was observed due to SUN levels being lower in the L/NoIMP cattle. To account for this, $\mathrm{d} 0$ was included as a covariate in the model. Heavy steers had greater $(P$ 


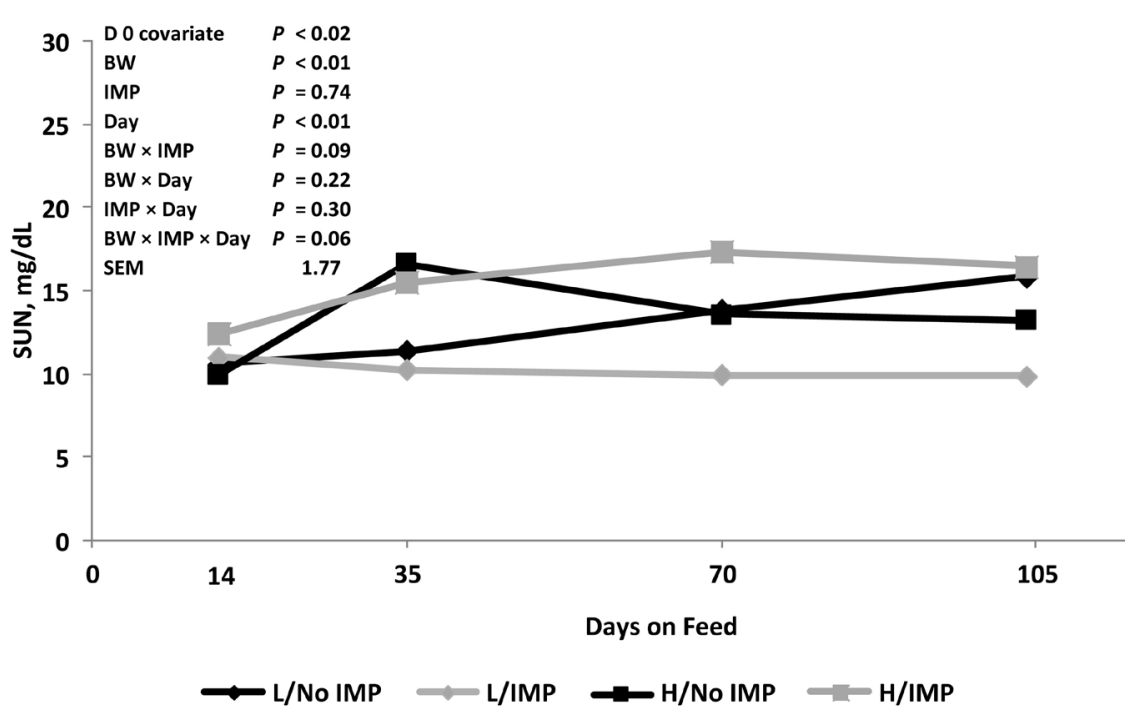

Figure 4. Effect of body weight class and implant usage on serum urea - $\mathrm{N}$ using d 0 values as a covariate $(\mathrm{L}=$ Light $\mathrm{BW}$; $\mathrm{H}=$ Heavy $\mathrm{BW}$; NoIMP $=$ Non-implanted; IMP = Implanted; SEM = 1.77; $\mathrm{n}=5$ steers/treatment).

$<0.01)$ SUN concentrations compared to L steers. Implanting steers had no effect $(P=0.74)$ on SUN concentrations across days. Which is not consistent to what others have demonstrated following steroidal implant administration [14] [17]. However, there was a tendency $(P<0.09)$ for a BW by implant interaction. Sera urea- $\mathrm{N}$ concentrations increased over time during the $104 \mathrm{~d}$ study for both $\mathrm{H}$ treatment groups and the L/NoIMP cattle whereas SUN concentrations remained low for the L/IMP cattle for the entire study.

Figures 5-14 show the effects of body weight and days on feed on right atrial and ventricular pressures as well as PAP (mean, systolic and diastolic). To our knowledge this is the first experiment that has evaluated the influence of BW a placement and implant administration on atrial and ventricular pressure in beef cattle. As mentioned previously there was no effect of implant administration $(P>0.13)$ on pulmonary measurements. Therefore, only the effects of BW and days on feed are reported. Right atrial pressure was not affected by BW $(P>$ $0.24)$. There was a tendency $(P=0.09)$ for right ventricular pressure to be affected by BW with ventricular pressure being elevated for the $\mathrm{H}$ cattle. In addition, overall pulmonary arterial pressure was affected $(P<0.01$; Figure 11$)$ by BW. The $\mathrm{H}$ steers exhibited elevated pulmonary arterial pressure when compared to $\mathrm{L}$ steers. In addition, day $(P<0.01)$ was different in almost every parameter measured highlighting differences in pressures measurements with increasing days on feed and increased BW as the duration of days on feed increased. Pulmonary arterial pressure measurements decreased with increasing days on feed. Finally, heart rate was lower $(P=0.02)$ in the $\mathrm{H}$ steers. This is because heart rate is inversely related to BW.

\section{Conclusion}

Steroidal implant administration increased growth performance responses as 

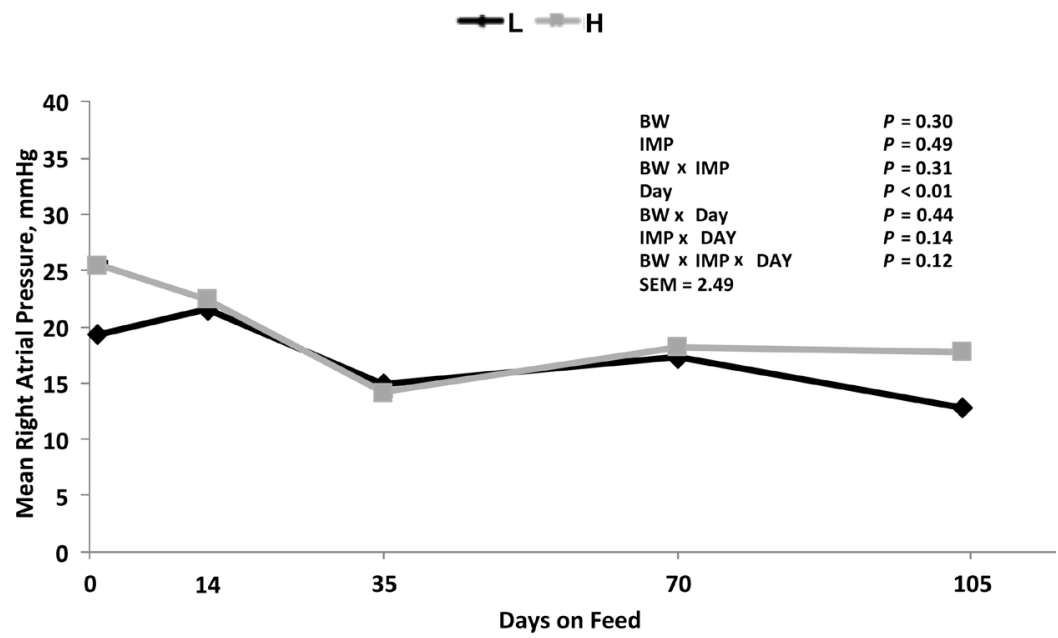

Figure 5. Effect of body weight and days on feed on mean right atrial pressure ( $\mathrm{L}=\mathrm{Light}$ BW; H = Heavy BW; SEM = 2.49; $\mathrm{n}=10$ ).

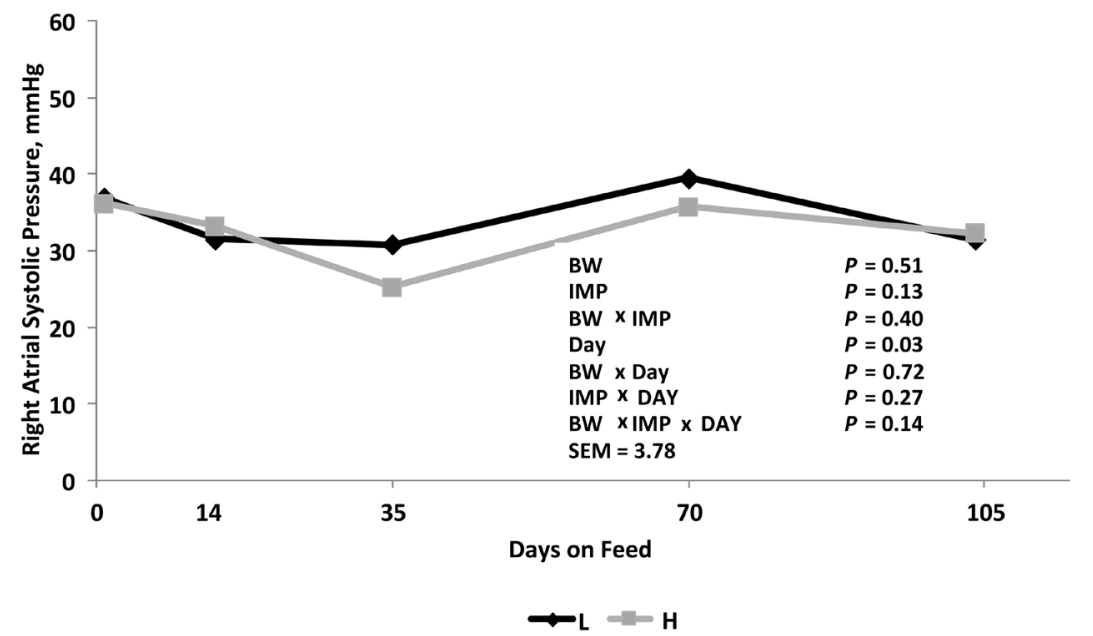

Figure 6. Effect of body weight and days on feed on systolic right atrial pressure $(\mathrm{L}=$ Light BW; H = Heavy BW; SEM = 3.78; $\mathrm{n}=10$ ).

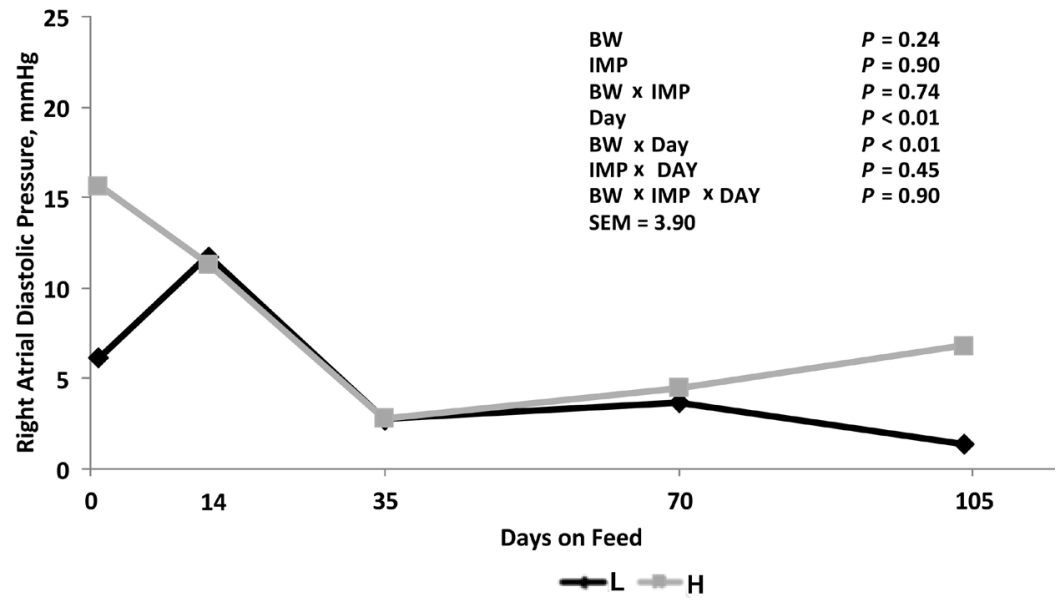

Figure 7. Effect of body weight and days on feed on diastolic right atrial pressure ( $\mathrm{L}=$ Light BW; H = Heavy BW; SEM = 3.90; $\mathrm{n}=10$ ). 


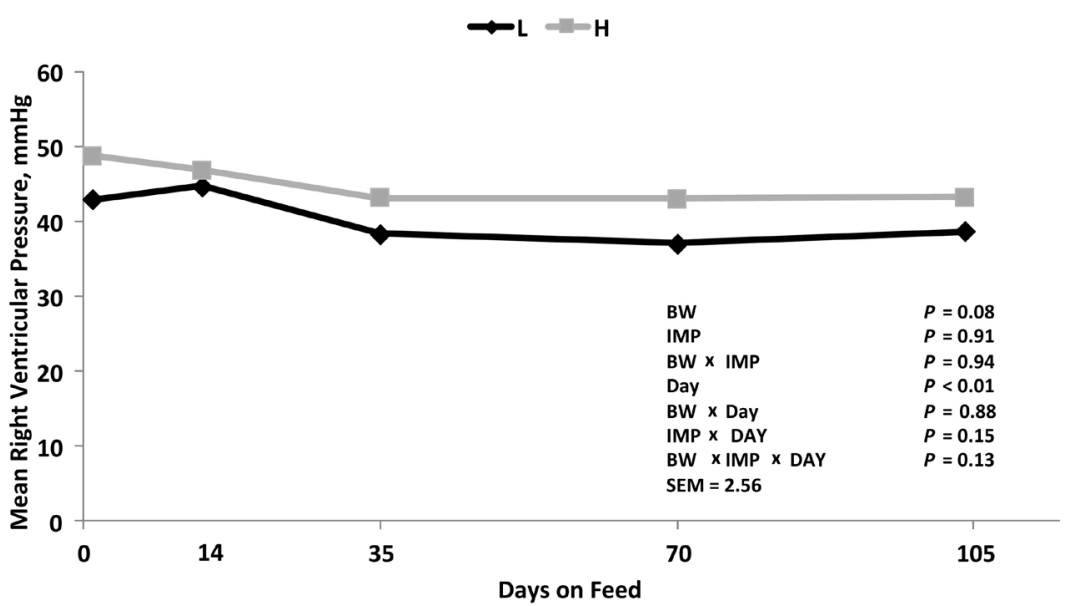

Figure 8. Effect of body weight and days on feed on mean right ventricular mean pressure $(\mathrm{L}=$ Light $\mathrm{BW} ; \mathrm{H}=$ Heavy BW; SEM = 2.56; $\mathrm{n}=10)$.

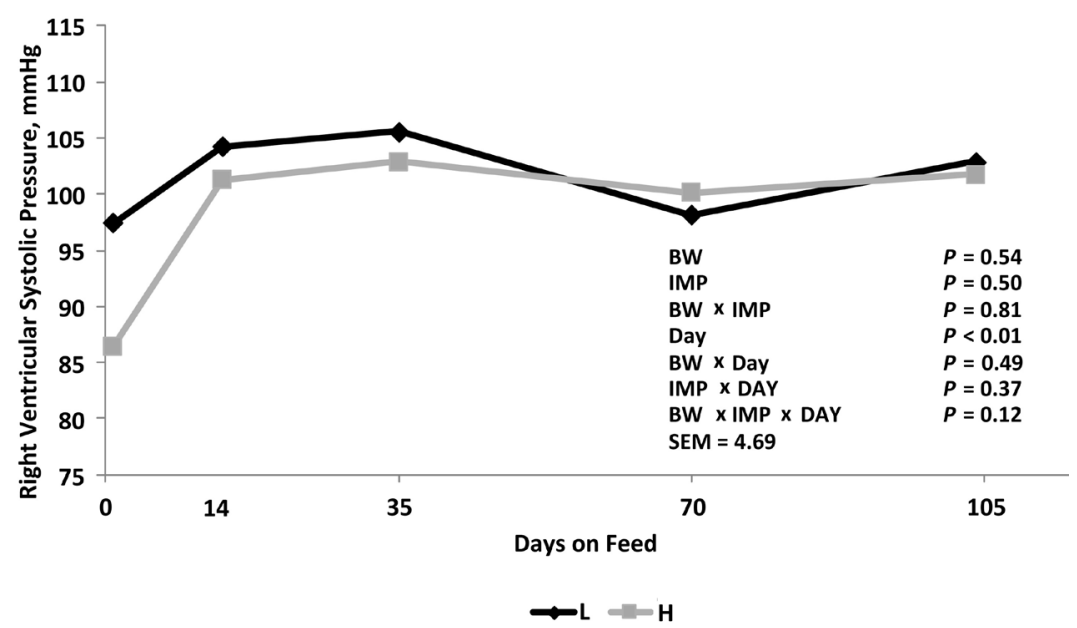

Figure 9. Effect of body weight and days on feed on systolic right ventricular pressure (L = Light $\mathrm{BW} ; \mathrm{H}=$ Heavy BW; SEM = 4.69; $\mathrm{n}=10$ ).

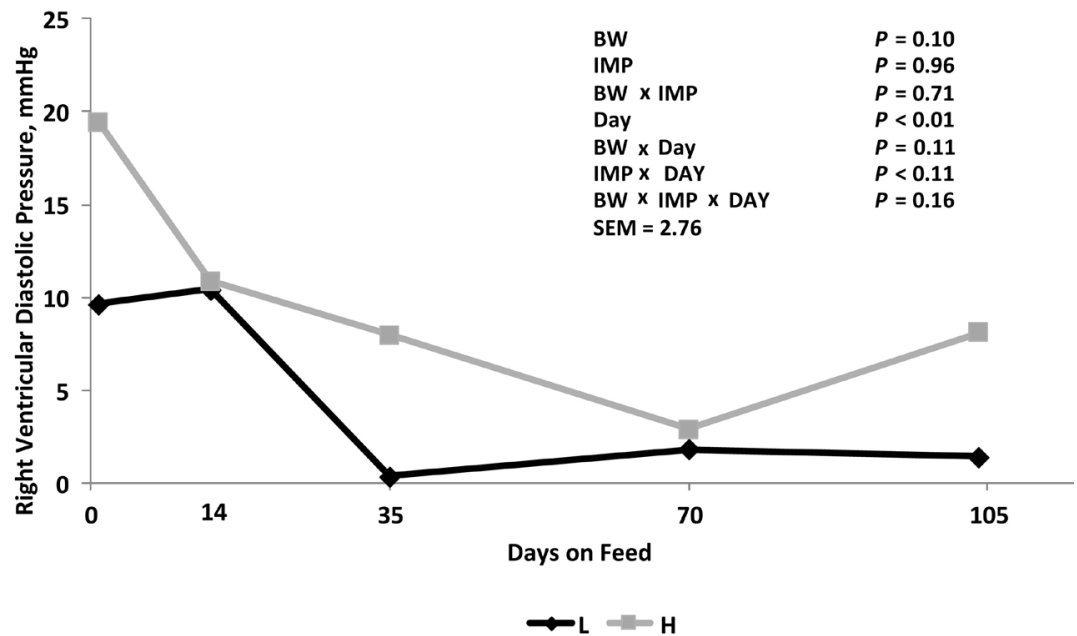

Figure 10. Effect of body weight and days on feed on diastolic right ventricular pressure $(\mathrm{L}=$ Light BW; $\mathrm{H}=$ Heavy BW; SEM = 2.76; $\mathrm{n}=10$ ). 


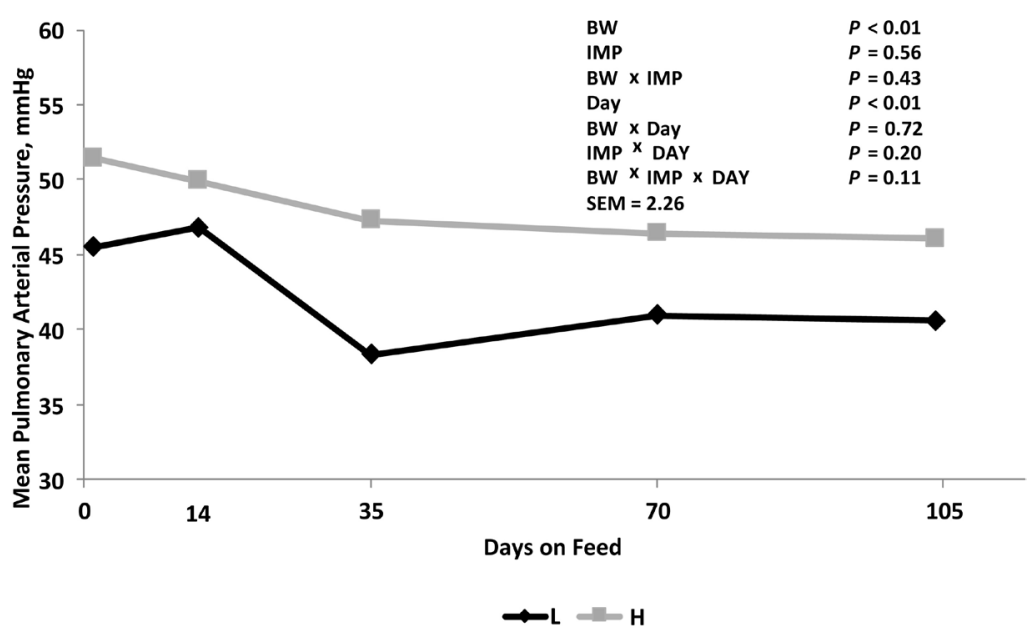

Figure 11. Effect of body weight and days on feed on mean pulmonary arterial pressure ( $\mathrm{L}=$ Light BW; H = Heavy BW; SEM = 2.26; $\mathrm{n}=10$ ).

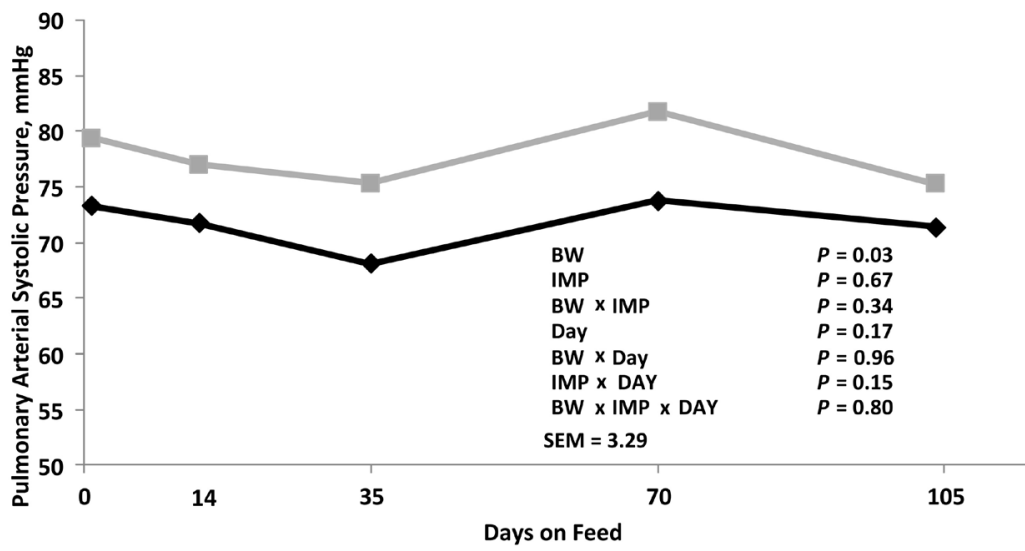

$\rightarrow \mathrm{L}=\mathrm{H}$

Figure 12. Effect of body weight and days on feed on systolic pulmonary arterial pressure ( $\mathrm{L}=$ Light BW; H = Heavy BW; SEM = 3.29; $\mathrm{n}=10$ ).

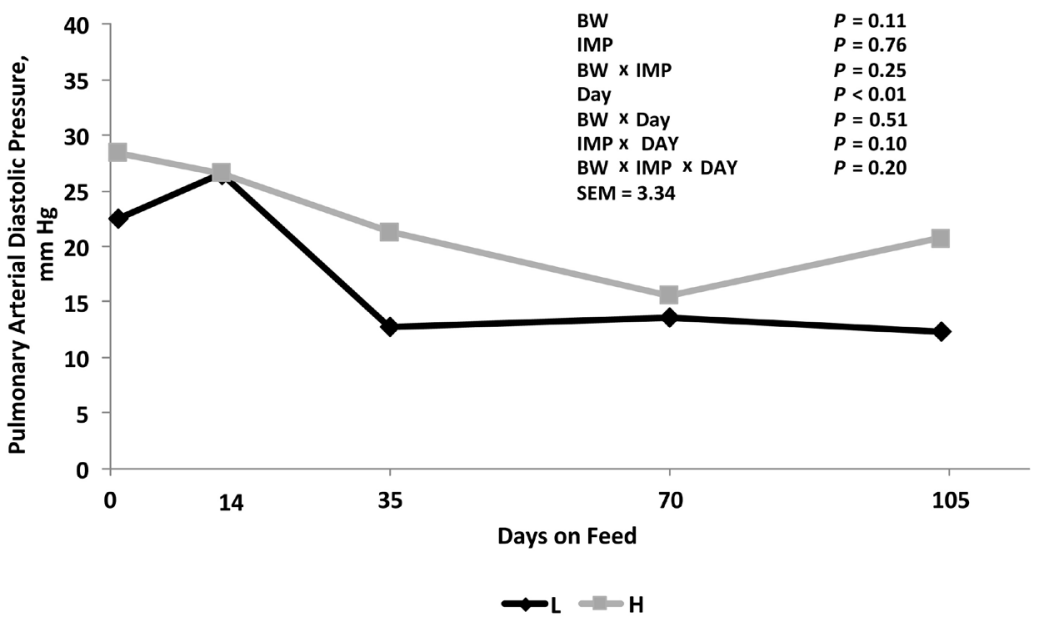

Figure 13. Effect of body weight and days on feed on diastolic pulmonary arterial pressure $(\mathrm{L}=$ Light $\mathrm{BW} ; \mathrm{H}=$ Heavy BW; $\mathrm{SEM}=3.34 ; \mathrm{n}=10)$. 


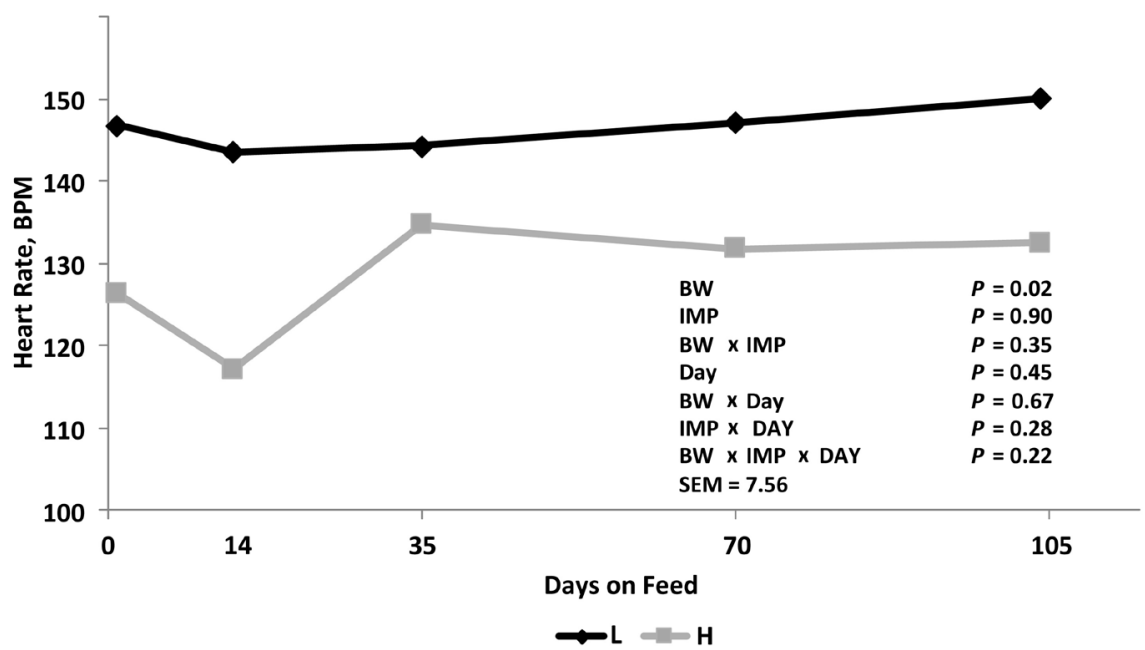

Figure 14. Effect of body weight and days on feed on heart rate $(\mathrm{L}=$ Light $\mathrm{BW} ; \mathrm{H}=$ Heavy BW; SEM = 7.56; $\mathrm{n}=10$ ).

expected. Regardless of BW at time of implantation, implants increased animal growth performance and carcass characteristics. Cattle of differing size respond to implants differently as evidenced by the changes in NEFA and SUN post-implantation. It is unlikely that steroidal implants with anabolic activity containing $\mathrm{E}_{2}$ and/or TBA impact pulmonary arterial pressure in feedlot steers under normal conditions. A limitation to this study is that cattle were housed in small pens. In larger pens settings, behavioral modifications and pen based social dynamics might have altered observed outcomes. However, the study highlights the risk of elevated BW on pulmonary arterial pressure.

\section{Supported}

Supported in part by funding from the Gordon W. Davis Regent's Chair in Meat Science and Muscle Biology Endowment at Texas Tech University.

\section{Conflicts of Interest}

The authors declare no conflicts of interest regarding the publication of this paper.

\section{References}

[1] Smith, Z.K. and Johnson, B.J. (2020) Mechanisms of Steroidal Implants to Improve Beef Cattle Growth: A Review. Journal of Applied Animal Research, 48, 133-141. https://doi.org/10.1080/09712119.2020.1751642

[2] Johnson, B.J. and Beckett, J. (2014) Application of Growth Enhancing Compounds in Modern Beef Production Executive Summary. American Meat Association Reference Paper for 2014, 1-15. https://doi.org/10.1787/9789264225503-4-en

[3] Reinhardt, C. (2007) Growth-Promotant Implants: Managing the Tools. Veterinary Clinics of North America: Food Animal Practice, 23, 309-319. https://doi.org/10.1016/j.cvfa.2007.03.004

[4] Vogel, G.J., Bokenkroger, C.D., Rutten-Ramos, S.C. and Bargen, J.L. (2015) A Re- 
trospective Evaluation of Animal Mortality in US Feedlots. The Bovine Practitioner, 49, 113-123.

[5] Neary, J.M., Booker, C.W., Wildman, B.K. and Morley, P.S. (2016) Right-Sided Congestive Heart Failure in North American Feedlot Cattle. Journal of Veterinary Internal Medicine, 30, 326-334. https://doi.org/10.1111/jvim.13789

[6] Ashraf, M.S. and Vongpatanasin, W. (2006) Estrogen and Hypertension. Current Hypertension Reports, 8, 368-376. https://doi.org/10.1007/s11906-006-0080-1

[7] Dubey, R.K., Oparil, S., Imthurn, B. and Jackson, E.K. (2002) Sex Hormones and Hypertension. Cardiovascular Research, 53, 688-708. https://doi.org/10.1016/S0008-6363(01)00527-2

[8] Umar, S., Rabinovitch, M. and Eghbali, M. (2012) Estrogen Paradox in Pulmonary Hypertension: Current Controversies and Future Perspectives. American Journal of Respiratory and Critical Care Medicine, 186, 125-131. https://doi.org/10.1164/rccm.201201-0058PP

[9] Smith, Z., Thompson, A., Hutcheson, J., Nichols, W. and Johnson, B. (2018) Evaluation of Long Acting Combination Implants Containing Trenbolone Acetate and Estradiol-17 $\beta$ on Live Performance, Carcass Traits, and Sera Metabolites in Finishing Steers. Journal of Animal Science, 96, 82-83. https://doi.org/10.1093/jas/sky073.153

[10] Holt, T.N. and Callan, R.J. (2007) Pulmonary Arterial Pressure Testing for High Mountain Disease in Cattle. Veterinary Clinics of North America: Food Animal Practice, 23, 575-596. https://doi.org/10.1016/j.cvfa.2007.08.001

[11] Smith, Z.K., Holland, B.P., Word, A.B., Crawford, G.I., Nichols, W.N., Nuttelman, B.L., Streeter, M.N., Hutcheson, J.P. and Johnson, B.J. (2019) Effects of a Single Initial and Delayed Release Implant on Arrival Compared with a Non-Coated Initial Implant and a Non-Coated Terminal Implant in Heifers Fed across Various Days on Feed. Translational Animal Science, 3, 1182-1193. https://doi.org/10.1093/tas/txz127

[12] Guiroy, P.J., Fox, D.G., Tedeschi, L.O., Baker, M.J. and Cravey, M.D. (2001) Predicting Individual Feed Requirements of Cattle Fed in Groups. Journal of Animal Science, 79, 1983-1995. https://doi.org/10.2527/2001.7981983x

[13] Guiroy, P.J., Tedeschi, L.O., Fox, D.G. and Hutcheson, J.P. (2002) The Effects of Implant Strategy on Finished Body Weight of Beef Cattle. Journal of Animal Science, 80, 1791-1800. https://doi.org/10.2527/2002.8071791x

[14] Smith, Z.K., Thompson, A.J., Hutcheson, J.P., Nichols, W.T. and Johnson, B.J. (2018) Evaluation of Coated Steroidal Implants Containing Trenbolone Acetate and Estradiol-17 $\beta$ on Live Performance, Carcass Traits, and Sera Metabolites in Finishing Steers. Journal of Animal Science, 96, 1704-1723. https://doi.org/10.1093/jas/sky095

[15] Blackwell, B.R., Brown, T.R., Broadway, P.R., Buser, M.D., Brooks, J.C., Johnson, B.J., Cobb, G.P. and Smith, P.N. (2014) Characterization of Trenbolone Acetate and Estradiol Metabolite Excretion Profiles in Implanted Steers. Environmental Toxicology and Chemistry, 33, 2850-2858. https://doi.org/10.1002/etc.2757

[16] Smith, Z.K., Kim, J.K. and Johnson, B.J. (2019) Biological Responses to Coated and Non-Coated Steroidal Implants Containing Trenbolone Acetate and Estradiol Benzoate in Finishing Steers. Journal of Animal Science.

[17] Parr, S., Brown, T., Ribeiro, F., Chung, K., Hutcheson, J., Blackwell, B., Smith, P. and Johnson, B. (2014) Biological Responses of Beef Steers to Steroidal Implants and Zilpaterol Hydrochloride. Journal of Animal Science, 92, 3348-3363. 
https://doi.org/10.2527/jas.2013-7221

[18] Littell, R.C., Henry, P.R. and Ammerman, C.B. (1998) Statistical Analysis of Repeated Measures Data Using SAS Procedures. Journal of Animal Science, 76, 1216-1231. https://doi.org/10.2527/1998.7641216x

[19] Johnson, B., Anderson, P., Meiske, J. and Dayton, W. (1996) Effect of a Combined Trenbolone Acetate and Estradiol Implant on Feedlot Performance, Carcass Characteristics, and Carcass Composition of Feedlot Steers. Journal of Animal Science, 74, 363-371. https://doi.org/10.2527/1996.742363x

[20] Parr, S., Chung, K., Galyean, M., Hutcheson, J., Dilorenzo, N., Hales, K., May, M., Quinn, M., Smith, D. and Johnson, B. (2011) Performance of Finishing Beef Steers in Response to Anabolic Implant and Zilpaterol Hydrochloride Supplementation. Journal of Animal Science, 89, 560-570. https://doi.org/10.2527/jas.2010-3101

[21] Parr, S., Chung, K., Hutcheson, J., Nichols, W., Yates, D., Streeter, M., Swingle, R., Galyean, M. and Johnson, B. (2011) Dose and Release Pattern of Anabolic Implants Affects Growth of Finishing Beef Steers across Days on Feed. Journal of Animal Science, 89, 863-873. https://doi.org/10.2527/jas.2010-3447

[22] Smith, Z., Baggerman, J., Kim, J., Wellmann, K. and Johnson, B. (2018) Biological Responses to Non-Coated and Coated Steroidal Implants Containing Equal Doses and Ratios of Trenbolone Acetate and Estradiol Benzoate in Beef Steers. Journal of Animal Science, 96, 234-235. https://doi.org/10.1093/jas/sky404.511

[23] Bryant, T.C., Engle, T.E., Galyean, M.L., Wagner, J.J., Tatum, J.D., Anthony, R.V. and Laudert, S.B. (2010) Effects of Ractopamine and Trenbolone Acetate Implants with or without Estradiol on Growth Performance, Carcass Characteristics, Adipogenic Enzyme Activity, and Blood Metabolites in Feedlot Steers and Heifers. Journal of Animal Science, 88, 4102-4119. https://doi.org/10.2527/jas.2010-2901 